\title{
GAMIFICAÇÃO NO ENSINO DE MATEMÁTICA
}

\author{
Relato de Experiência \\ Emanuela Vitória Dias Morais ${ }^{1}$ \\ Marciene Pacheco ${ }^{2}$ \\ Albertina Marília Alves Guedes ${ }^{3}$ (Orientadora)
}

\section{INTRODUÇÃO}

Gamificação, segundo Blanco (2015), é uma técnica que usa jogos ou elementos de jogos em situações que não são brincadeira, mas que podem ter objetivos pedagógicos de aprendizagem. Neste tipo de jogo é valorizada a cooperação e resolução de problemas visando superar níveis de dificuldades e/ou desafios propostos pelo professor. Nestas atividades também tem como principal finalidade motivar os participantes à uma determinada ação de aprendizagem visto que auxiliar na solução de problemas e promove aprendizagem (KAPP, 2012). De acordo com Werbach e Hunter (2012), a gamificação é própria para ser utilizada em contextos que são ou que podem se tornar divertidos, mas que são direcionados à realização de objetivos específicos de aprendizagem, tais como, o contexto escolar.

\section{RELATO DE EXPERIÊNCIA}

O presente relato diz respeito a uma experiência vivenciada na execução de um projeto pedagógico realizado com 20 alunos do $1^{\circ}$ ano do Ensino Fundamental 1 em uma escola da rede municipal na cidade de Petrolina-PE. A atividade aplicada pretendia desenvolver a capacidade de organização do pensamento lógico dos alunos, possibilitar uma melhor apreensão dos conteúdos matemáticos de adição, e, estimular a realização de atividades em equipe e de modo colaborativo.

Inicialmente estimulamos os alunos a participarem da atividade Caça ao Tesouro (Imagem 1). Para a realização desta atividade os alunos foram encaminhados para a quadra de esportes da escola. Posteriormente, as crianças foram divididas em 4 subgrupos e entregue a cada subgrupo um mapa com a localização dos desafios aos quais conduziria os alunos até o tesouro.

\footnotetext{
${ }^{1}$ Estudante do curso de Licenciatura em Computação, IF Sertão PE, Campus Petrolina. E-mail: vitoriadm98@gmail.com ${ }^{2}$ Estudante do curso de Licenciatura em Computação, IF Sertão PE, Campus Petrolina. E-mail: marcienepacheco@gmail.com ${ }^{3}$ Professora do curso de Licenciatura em Computação, IF Sertão PE, Campus Petrolina. E-mail: albertina.guedes@ifsertao-pe.edu.br
} 
Para encontrar o tesouro cada subgrupo de alunos deveria percorrer um caminho compostos por 4 desafios matemáticos. Cada subgrupo deveria resolver um desafio diferente para decifrar o código de cada mapa (Imagem 2). Ressaltamos que cada desafio tinha uma "Letra". Desse modo, quando os 4 desafios eram resolvidos, formaria a palavra "Sala" que os levaria ao destino final - a Sala de Aula. Além disso, os desafios eram compostos por cálculos matemáticos e para facilitar a contagem, foram usados pirulitos e chocolates que simulavam joias e moedas.

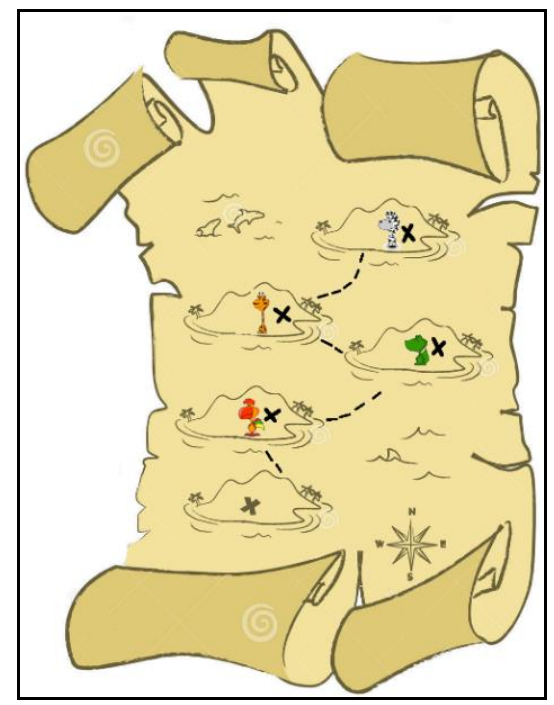

Imagem 1:

Mapa. Fonte: Própria

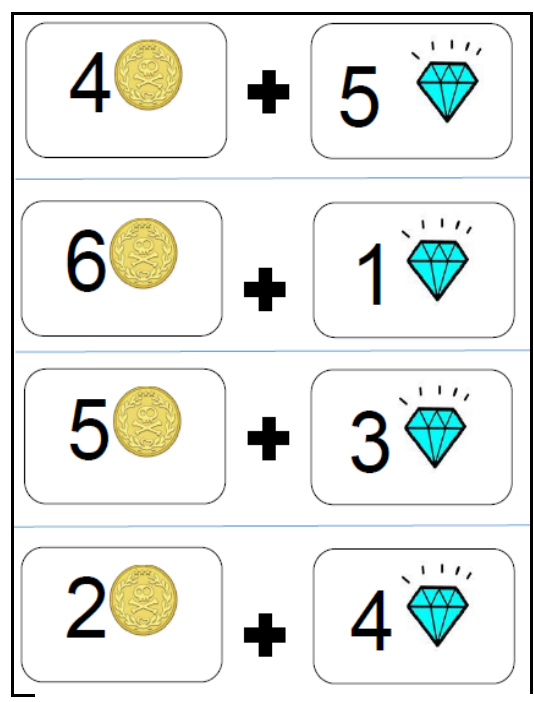

Imagem 2:

Desafios Fonte: Própria

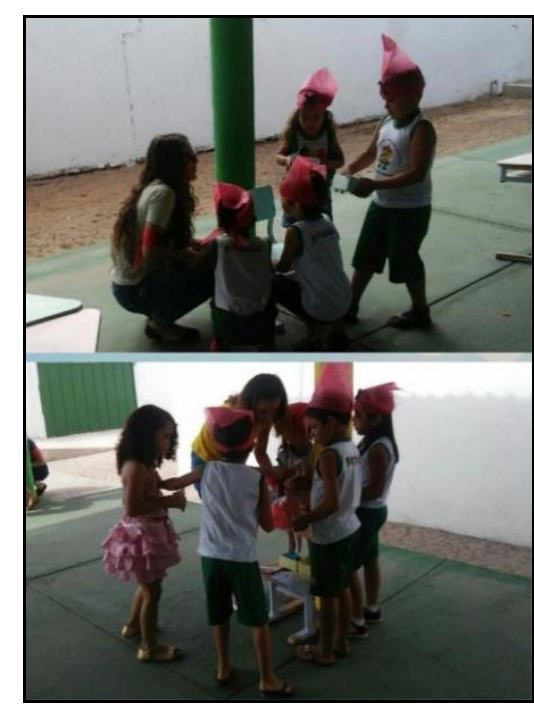

Imagem 3:

Culminância Fonte: Própria

\section{CONSIDERAÇÕES FINAIS}

Diante desta experiência, percebemos que o trabalho obteve respostas positivas visto que todos os alunos se envolveram com a realização da tarefa e puderam apreender melhor os conteúdos de adição de forma significativa através da gamificação, agregando ao ensino à ludicidade e com base nisso puderam atingir resultados satisfatórios no processo de aprendizagem dos conteúdos de adição (Imagem 3).

\section{REFERÊNCIAS}

BLANCO, G. Verbete Draft: o que é Gamification. 2015. Disponível em http://projetodraft.com/verbete-draft-o-que-e-gamification/\#sthash.B5g918CO.dpuf. Acesso em: 12 set 2016.

KAPP, K. The Gamification of Learning and Instruction: Game-based Methods and Strategies for Training and Education. Pfeiffer, 2012.

WERBACH, K; HUNTER, D. 2012. For The Win: How Game Thinking Can Revolutionize Your Business? Warthon Digital Press: Philadelphia. Disponível em: <http://wdp.wharton.upenn. edu/book/for-the-win/> . Acesso em: 12 set 2016. 